\title{
PERANCANGAN SISTEM MONITORING SUHU DAN KADAR AIR PAKAN IKAN PADA PURWARUPA PENGERING PAKAN IKAN MENGGUNAKAN VISUAL STUDIO
}

\author{
Zulkarnain*), Aris Triwiyatno, dan Sudjadi \\ Departemen Teknik Elektro, Universitas Diponegoro \\ Jl. Prof. Sudharto, SH, Kampus UNDIP Tembalang, Semarang 50275, Indonesia \\ ${ }^{*}$ E-mail: zulkarnainnain2@gmail.com
}

\begin{abstract}
ABSTRAK
Alat pengering pakan ikan di Lab FPIK (Fakultas Perikanan dan ilmu Kelautan) Universitas Diponegoro masih menggunakan monitoring secara manual sehingga kurang efektif. Oleh karena itu dibutuhkan monitoring yang baik untuk menangani permasalahan pada alat pengering pakan ikan di Lab FPIK UNDIP. Pada Penelitian ini dirancang sistem monitoring data suhu dan kadar air menggunakan LCD dan aplikasi Visual Studio. Pada Penelitian ini terdapat 3 pengujian antara lain pengujian LCD, form Visual Studio, dan pengujian alarm. Hasil pengujian monitoring suhu dan kadar air pakan ikan pada purwarupa pengering pakan ikan melalui LCD dan form Visual Studio berhasil berjalan dengan baik dengan jeda waktu pembacaan melalui Visual Studio sebesar 1 detik. Pengujian alarm pakan siap telah berhasil dilakukan ketika kelembaban mencapai 10\% RH dan kadar air sebesar 10\%. Pengujian alarm overheat telah behasil dilakukan ketika suhu mencapai $5^{\circ} \mathrm{C}$ diatas setpoint yang diberikan selama 10 detik. Dan pengujian below setpoint berhasil dilakukan ketika suhu tidak mencapai setpoint dalam rentang $5^{\circ} \mathrm{C}$ dibawah setpoint yang di berikan.
\end{abstract}

Kata Kunci: purwarupa pengering pakan ikan, sensor kadar air SEN0193, Sensor suhu dan kelembaban udara DHT22, mikrokontroler Atmega328P, Metode kontrol PI

\begin{abstract}
Fish feed dryer in the FPIK Lab (Faculty of Fisheries and Marine Sciences) Diponegoro University still uses manual monitoring so it is less effective. Therefore, a good monitoring is needed to deal with problems in the fish feed dryer in the FPIK UNDIP Lab. In this Final Project designed a temperature and water content monitoring system using LCD and Visual Studio applications. In this Final Project there are 3 tests including LCD testing, Visual Studio form, and alarm testing. The results of monitoring the temperature data and water content of fish feed on the prototype of fish feed dryer through LCD and Visual Studio form successfully went well with the reading delay through Visual Studio by 1 second. Ready feed alarm testing has been successfully carried out when humidity reaches 10\% RH and moisture content is $10 \%$. Overheat alarm testing has been performed when the temperature reaches $5^{\circ} \mathrm{C}$ above the given setpoint for 10 seconds. And the below setpoint test was successful when the temperature did not reach the setpoint in the range of $5^{\circ} \mathrm{C}$ below the given setpoint.
\end{abstract}

Keywords: Fish feed driers prototype, SENO193 moisture sensor, DHT22 temperature and air humidity sensor, Atmega328P microcontroller, PI control method

\section{Pendahuluan}

Pengendalian suhu dan kadar air di industri perikanan kini semakin berkembang pesat pada era modern sekarang ini, sehingga dibutuhkan pengendalian suhu dan kadar air yang stabil agar menghasilkan respon sistem sesuai dengan referensi, akan tetapi masih banyak pengendalian suhu dan kadar air di industri perikanan yang kurang efektif dan efisien dalam pengontrolan suhu dan kadar air, salah satunya pada kasus pengendalian suhu dan kelembaban di alat pengering pakan ikan yang berlokasi di laboratorium fakultas perikanan dan ilmu kelautan UNDIP. Dengan demikian diperlukan pengendalian suhu dan kadar air yang lebih efektif dan efisien.

Selain diperlukan sistem pengendalian yang tepat dalam proses pengeringan pakan ikan, diperlukan sistem monitoring terhadap alat pengering pakan ikan tersebut. Hal ini diperlukan karena meskipun pengeringan menggunakan alat, proses pengeringan dapat berjalan hingga lebih dari 24 jam. Kemampuan manusia yang terbatas untuk terus-menerus memantau alat secara langsung di tempat sehingga diperlukan sebuah sistem monitoring yang mampu membuat pengguna bisa memantau dan menyimpan data dari pengeringan pakan 
ikan menggunakan alat tersebut. Sistem yang dirancang dapat memberikan informasi mengenai parameter proses pengeringan pakan ikan seperti suhu dan kadar air serta mampu memberikan masukan seperti nilai referensi, nilai parameter kontrol dan perintah on-off kepada alat pengering pakan ikan tersebut.

Terdapat beberapa Penelitian yang telah dilakukan sebelumnya mengenai sistem monitoring data dan sistem monitoring berbasis nirkabel. Yosia Gita Mustikoaji merancang sistem monitoring dan kendali suhu pada oven kayu menggunakan minikomputer Raspberry Pi 3 dan Modul GSM [1]. Pada perancangan tersebut sistem berhasil mengirimkan data suhu yang ada pada oven kayu ke smartphone melalui jaringan pesan singkat (SMS). Hot Asi Yohannes merancang sistem akuisis data alat ukur arus, tegangan, hambatan dan suhu digital menggunakan koneksi Bluetooth pada ponsel cerdas Android [2]. Sistem tersebut berhasil mengirimkan data seluruh sensor ke dalam aplikasi android. Harum Amalia Sandi merancang sistem akuisisi data multisensor melalui website berbasis android [3]. Pada perancangan tersebut sistem berhasil mengirimkan data sensor melalui koneksi internet dan ditampilkan pada halaman web. Bagas Adi Luhung merancang sistem antarmuka berbasis hmi pada perangkat keras pengemasan air minum[4]. Pada Penelitian ini terdapat 4 pengujian yaitu pengujian pengontrolan, monitoring, delay dan database. Dari hasil 4 pengujian tersebut didapatkan sistem berjalan dengan baik. Pada pengujian pengontrolan tombol start dan stop, plant dapat dimulai dan dihentikan sesuai dengan keinginan. Pengujian monitoring, HMI dapat mengikuti segala kondisi pada plant. Pada pengujian delay di dapat adanya delay 0.59 detik antara komunikasi HMI dan PLC . Dan pada pengujian database semua informasi yang dibutuhkan dapat disimpan dengan baik pada MS access 2007. Erwin Adriono membuat perancangan sistem antarmuka berbasis hmi (human machine interface) pada mesin autoballpress plant di pt.apac inti corpora hmi [5]. Pada penelitian ini dilakukan pengujian untuk mengetahui keandalannya yaitu melalui pengujian sistem monitoring, pengujian sistem pengontrolan, pengujian sistem alarm dan pengujian sistem database. Pengujian monitoring menghasilkan bahwa HMI sudah dapat memantau kondisi plant dengan baik dan memiliki delay rata-rata 2,52 detik. Pengujian sistem pengontrolan menghasilkan bahwa HMI sudah dapat mengontrol plant. Pengujian alarm menunjukkan hasil bahwa alarm sudah dapat bekerja dengan baik. Pengujian database menunjukkan bahwa fungsi penyimpanan database pada HMI sudah dapat berjalan dengan baik. Secara keseluruhan HMI yang dirancang sudah dapat berjalan dengan baik.

Dalam Penelitian ini akan dirancang sistem monitoring data suhu dan kadar air pakan ikan menggunakan LCD dan Visual Studio. Sistem menggunakan mikrokontroler ATMega328P sebagai unit akuisisi data dan antarmuka pengguna. Sistem dirancang untuk mengirimkan data sensor suhu DHT22 dan sensor kadar air SKU:SEN0912 dari ATMega328P ke LCD dan aplikasi Visual Studio. Pengguna akan mengakses antarmuka pengguna melalui aplikasi Visual Studio yang telah dirancang. Selain itu antarmuka pengguna dapat memberikan masukan ke mikrokontroler seperti nilai referensi, nilai parameter kontrol, dan perintah on-off. Sistem tersebut bisa diakses oleh pengguna melalui jaringan nirkabel dalam hal ini adalah koneksi bluetooth.

\section{Metode \\ 2.1. Algoritma dan Diagram Alir Purwarupa Pengering Pakan Ikan}

Algoritma perangkat lunak dari interface secara keseluruhan adalah sebagai berikut:

a. Mulai.

b. Tampilan form login interface.

c. Masukkan username dan password. Jika username dan password salah maka akan dimunculkan peringatan username atau password salah, jika username = "pakanikan" dan password = "pakanikan" maka lanjut ke algoritma d.

d. Masuk ke tampilan menu utama, jika dipilih mode Auto maka akan masuk mode close loop, jika dipilih mode Manual maka masuk mode open loop, jika dipilih logout maka kembali ke tampilan form login, jika tidak maka kembali ke tampilan menu utama.

e. Selesai.

Berdasarkan algoritma interface keseluruhan dapat disusun diagram alir dari interface secara keseluruhan yang ditunjukkan pada Gambar 1.

Berdasarkan algoritma dan diagram alir keseluruhan dari bagian form Menu Utama yang ditunjukkan pada Gambar4 terdapat mode Auto dan mode Manual, apabila dipilih process Auto maka algoritmanya sebagai berikut :

a. Mulai.

b. Pilih port usb untuk komunikasi data, pilih connect untuk mengambil data dari mikrokontroler, jika klik disconnect maka akan memutus komunikasi data[6].

c. Menentukan nilai setpoint yang diinginkan $\left(50-60^{\circ} \mathrm{C}\right)$, kemudian tekan tombol "SEND" (mode Auto).

d. Menentukan nilai u (\%) yang diinginkan (0-100\%), kemudian tekan tombol "SEND" (mode Manual).

e. Penerimaan data proses close loop dari mikrokontroler.

f. Klik tombol "SAVE DATA" untuk menyimpan data berupa excel jika berhasil akan muncul message box : "export succesfull", jika tidak lanjut algoritma $\mathrm{f}$.

g. Klik tombol "SAVE GRAPHIC" untuk menyimpan grafik, jika tidak lanjut algoritma g.

h. Klik tombol "CLEAR" untuk menghapus data grafik yang sedang masuk, jika tidak lanjut algoritma $h$.

i. Klik tombol "STOP" untuk mengentikan proses sistem. 


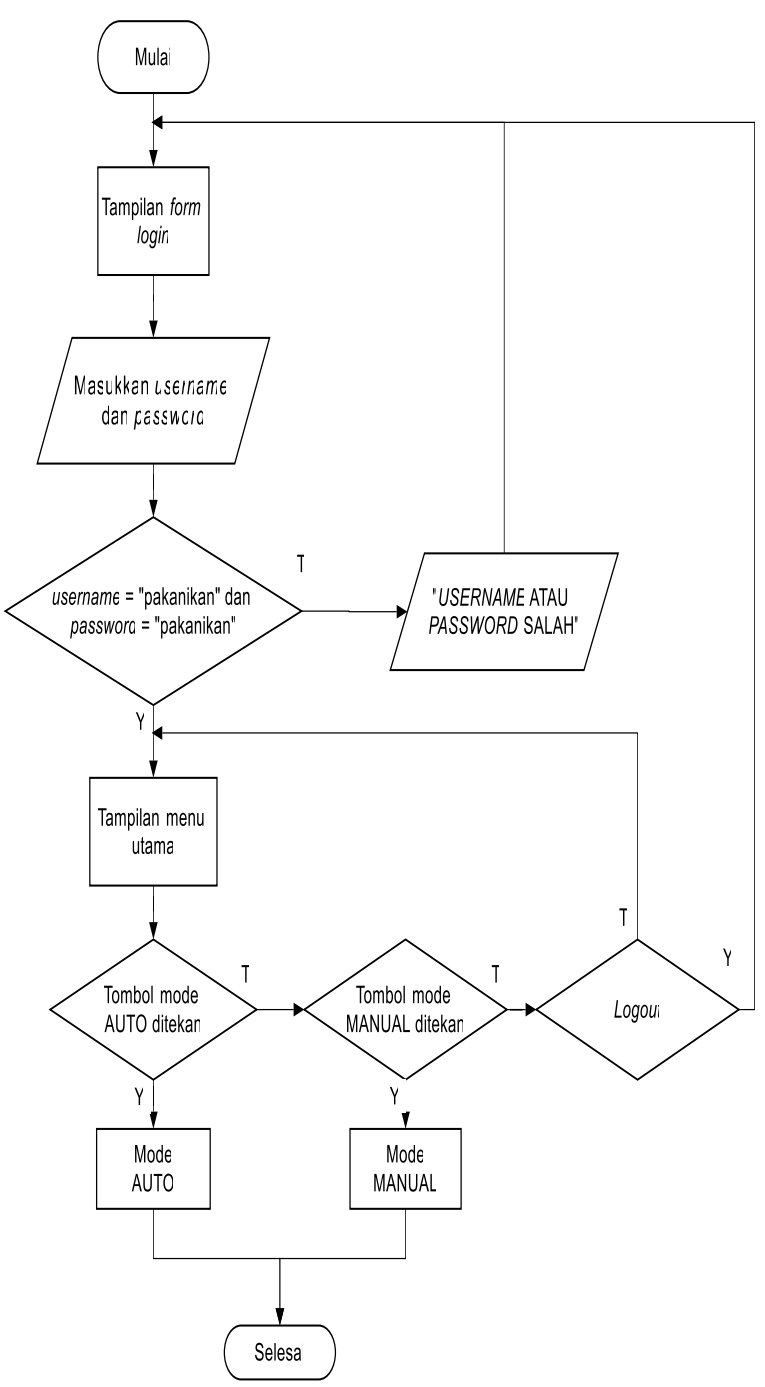

Gambar 1. Algoritma perangkat lunak dari interface secara keseluruhan

j. Klik tombol "DISCONNECT" untuk menghentikan data yang masuk ke form Mode Auto.

k. Klik tombol "HOME" untuk kembali ke menu utama.

1. Selesai.

Berdasarkan algoritma diatas, mode Manual dapat disusun diagram alir yang ditunjukkan pada Gambar 2. Sedangkan algoritma mode Auto, dapat disusun diagram alir yang ditunjukkan pada Gambar 3.

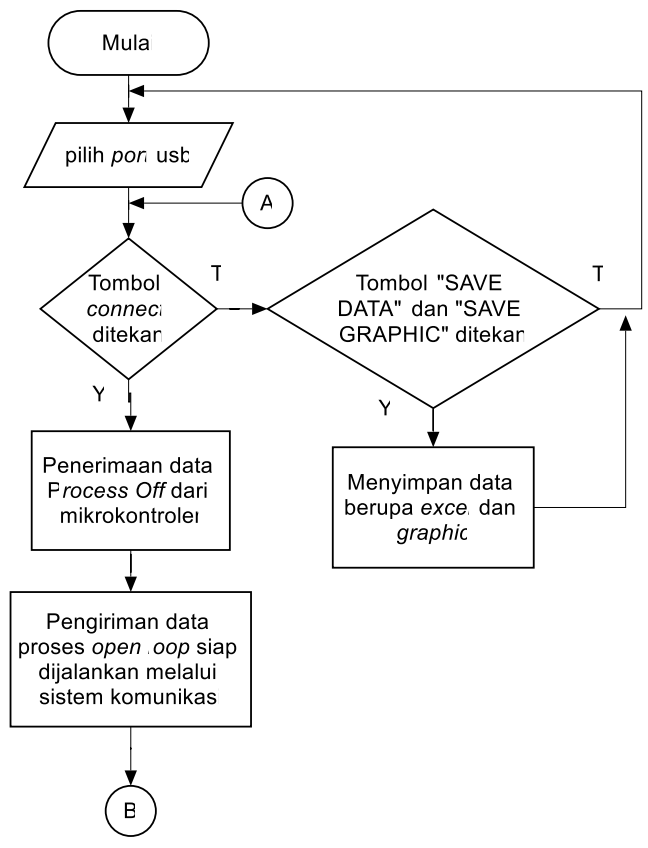

(a)

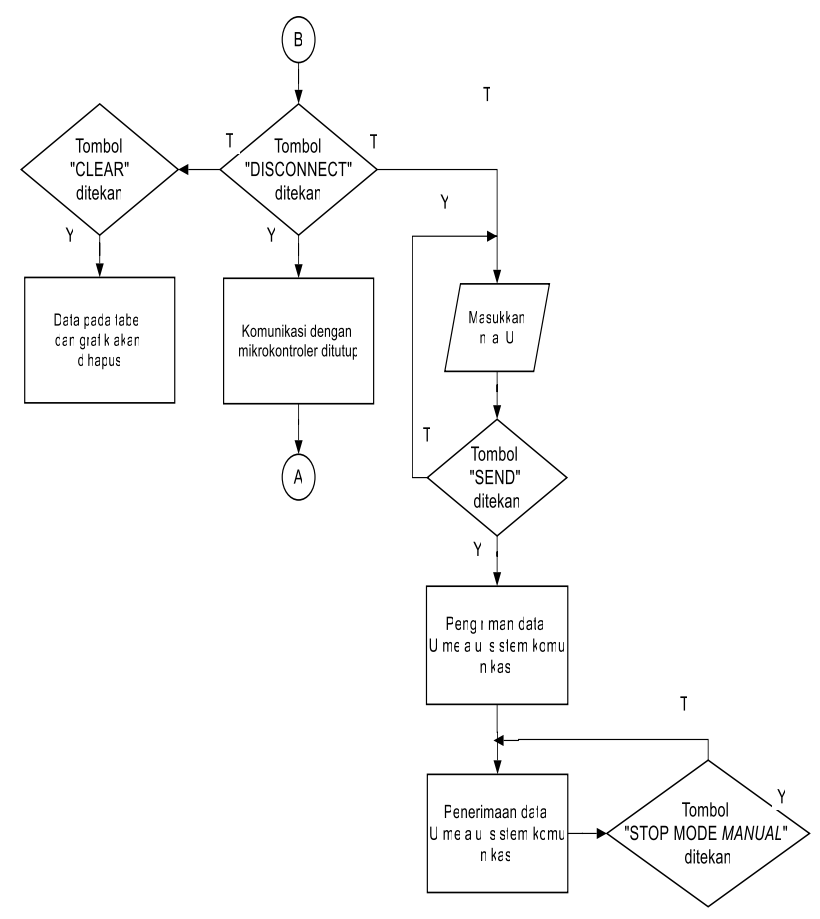

(b)

Gambar 2. Diagram alir mode Manual. 


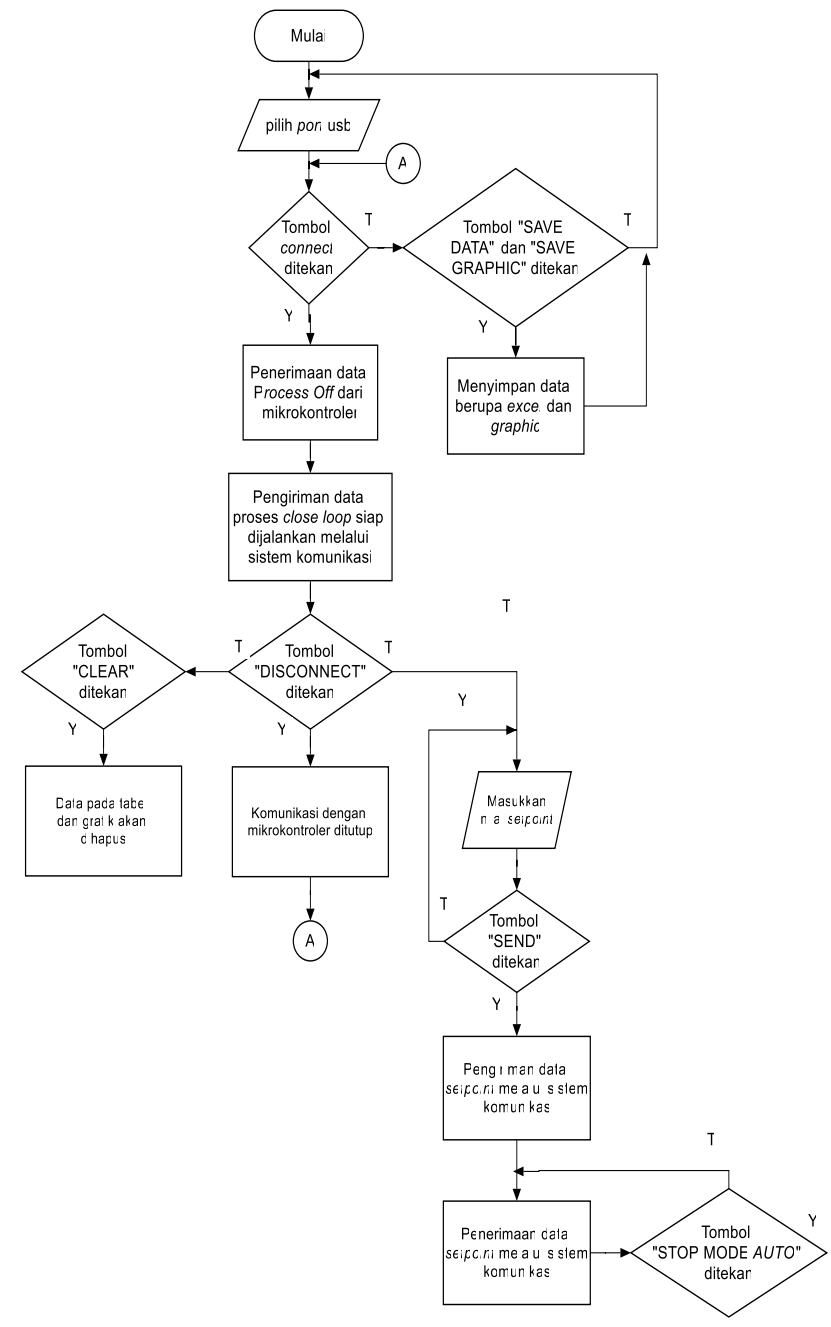

Gambar 3. Diagram alir mode Auto.

\subsection{Perancangan Interface}

Interface pada Penelitian ini digunakan sebagai antarmuka antara user dan plant alat pengering pakan ikan. Selain memberikan informasi mengenai plant pada user, user juga dapat melakukan pengendalian terhadap plant melalui interface[7]. Penelitian ini memeiliki 2 macam interface, yaitu interface berupa hardware dan berupa software.

Interface berupa hardware merupakan interface yang dirancang menggunakan lcd dan push button sebagai komponen utama. Interface ini diletakkan di panel box menghadap ke depan.

Pada interface berupa hardware, interface menampilkan nilai suhu saat ini, referensi suhu, referensi sinyal kontrol, nilai kelembaban pakan ikan yang diperoleh dari sensor SEN0193, dan kelembaban ruangan pengering pakan ikan.
Tampilan layar 1 dan 2 mode Auto pada LCD dapat dilihat pada Gambar 4 di bawah ini.

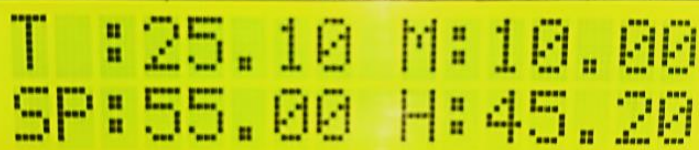

(a) Layar 1

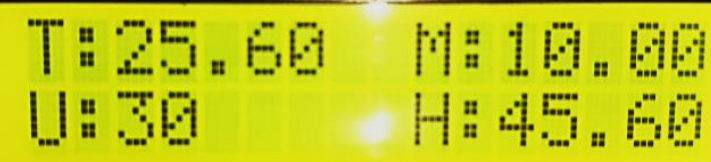

(b) Layar 2

\section{Gambar 4. Tampilan layar mode Auto pada LCD}

Interface berupa software terbagi menjadi 4 bagian yaitu form Login, form Menu Utama, form proses Auto, dan form proses Manual.

\section{Perancangan form Login}

Form Login dirancang untuk meningatkan keamanan dan membatasi pengguna interface melalui Visual Studio[8]. Form ini mengharuskan pengguna mengisikan username dan password. Jika username dan password benar, maka pengguna dapat melanjutkan ke form selanjutnya yaiu form Menu Utama. Gambar 5 menunjukkan tampilan dari form Login.

\section{Perancangan form menu utama}

Form menu utama dapat diakses setelah pengguna melakukan login. Gambar 6 menunjukkan tampilan form Menu Utama. Dari Gambar 6 dapat terlihat bahwa tampilan form Menu Utama terdapat 2 pilihan mode, yaitu mode Auto dan mode Manual.

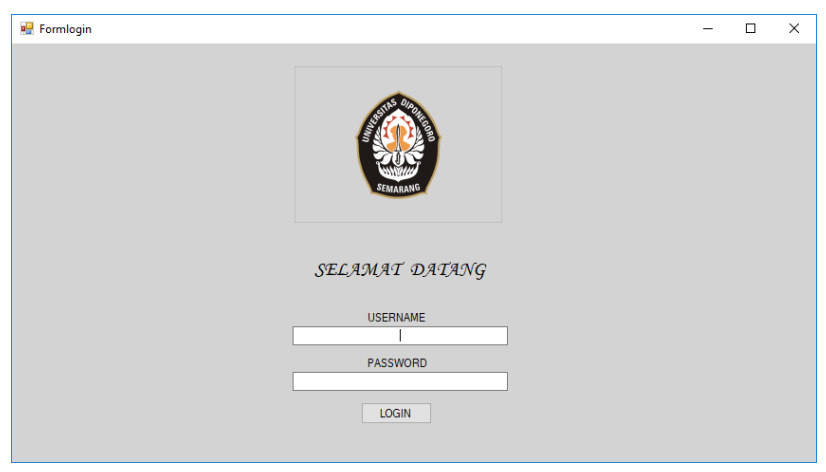

Gambar 5. Tampilan form Login 


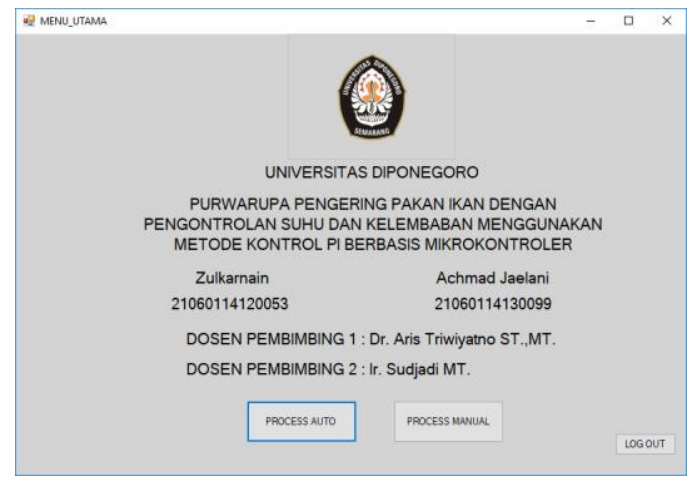

Gambar 6. Tampilan form menu utama.

3. Perancangan form mode Auto dan Manual mode Auto dan Manual dapat diakses ketika tombol pada mode Auto atau mode Manual ditekan. Gambar 7 menunjukkan tampilan interface mode Auto. Sedangkan Gambar 8 menunjukkan tampilan interface mode Manual.

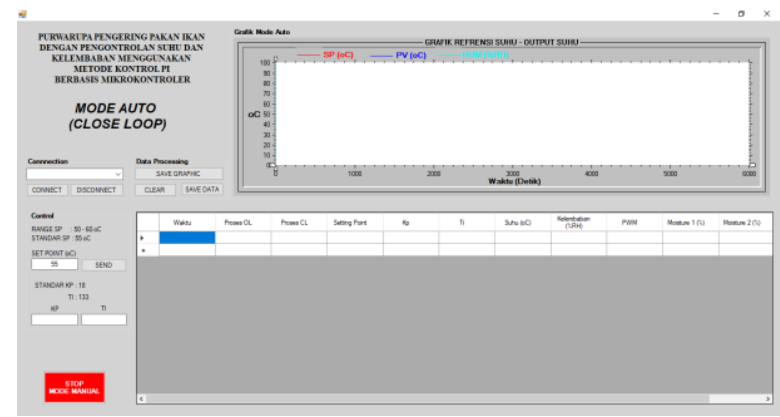

Gambar 7. Tampilan form mode Auto.

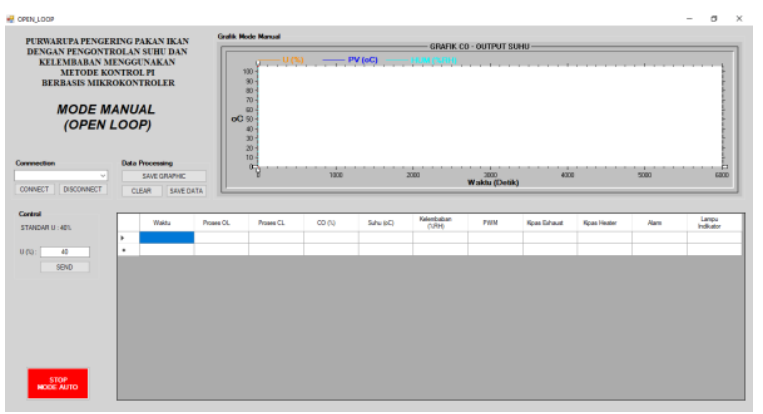

Gambar 8. Tampilan form mode Manual.

Berdasarkan Gambar 7 dan Gambar 8 terdapat 6 tombol yaitu sebagai berikut:

a. Tombol connect

Tombol yang berfungsi untuk membuka komunikasi antara penerima sinyal kontrol dengan pengirim sinyal kontrol.

b. Tombol disconnect

Tombol yang berfungsi untuk menutup komunikasi antara penerima sinyal kontrol dengan pengirim sinyal kontrol.

c. Tombol clear
Tombol yang berfungsi untuk menutup menghapus data yang ditampilkan pada tabel di datagridview dan grafik.

d. Tombol save data dan save graphic

Tombol yang berfungsi untuk menyimpan data dan menyimpan grafik.

e. Tombol Send

Tombol yang berfungsi untuk mengirimkan nilai setpoint (pada mode Auto) atau nilai sinyal kontrol (pada mode Manual) ke penerima sinyal kontrol[9].

f. Tombol stop process $\mathrm{cl}$

Tombol yang berfungsi untuk mengirimkan perintah untuk menghentikan sistem.

\section{Hasil dan Analisis \\ 3.1. Pengujian Interface \\ 3.1.1. Pengujian form Login}

Pengujian form Login yang dilakukan yaitu pengujian username dan password jika diisikan benar dan pengujian username dan password diisikan salah. Pengujian username dan password benar dilakukan dengan mengisikan username dan password yang sesuai. Hasil dari pengujian username dan password benar ditunjukkan pada Gambar 9.

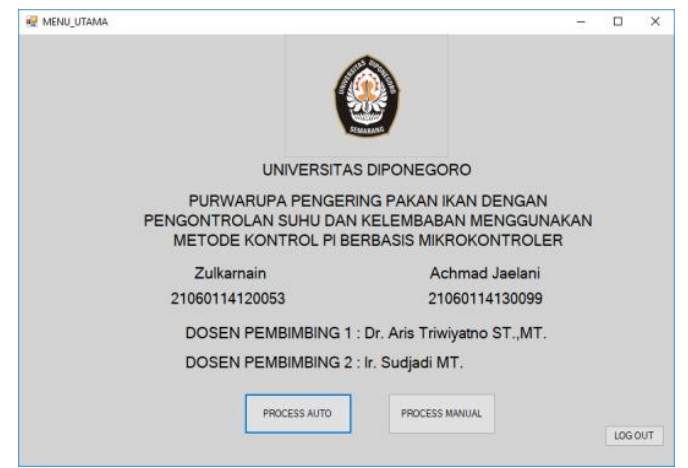

Gambar 9. Tampilan Login berhasil dan masuk ke dalam form Menu Utama

Pengujian username dan password salah dilakukan dengan mengisikan username dan password yang tidak sesuai. Hasil dari pengujian username dan password salah ditunjukkan pada Gambar 10.

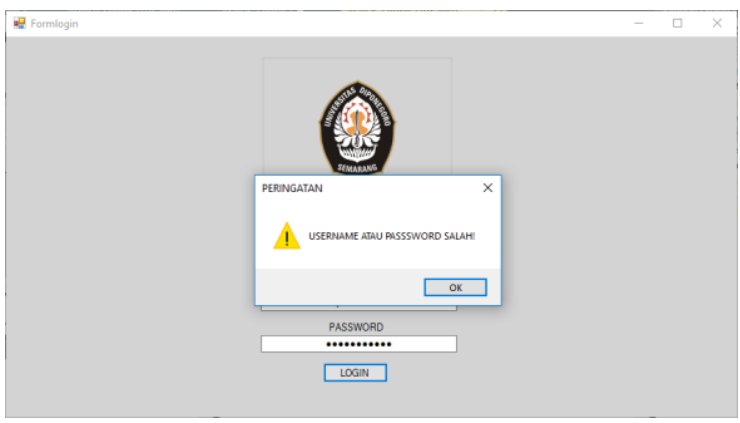




\section{Gambar 10. Hasil pengujian username dan password} salah.

\subsubsection{Pengujian form mode Auto}

Pada form mode Auto pengujian dilakukan dengan melakukan pengetesan koneksi port, pemberian nilai setpoint, $\mathrm{Kp}$ dan $\mathrm{Ti}$, penyimpanan grafik, dan penyimpanan data tabel. Pengujian pertama yaitu pemberian nilai setpoint. Gambar 11 menunjukkan hasil pengujian pemberian nilai setpoint.

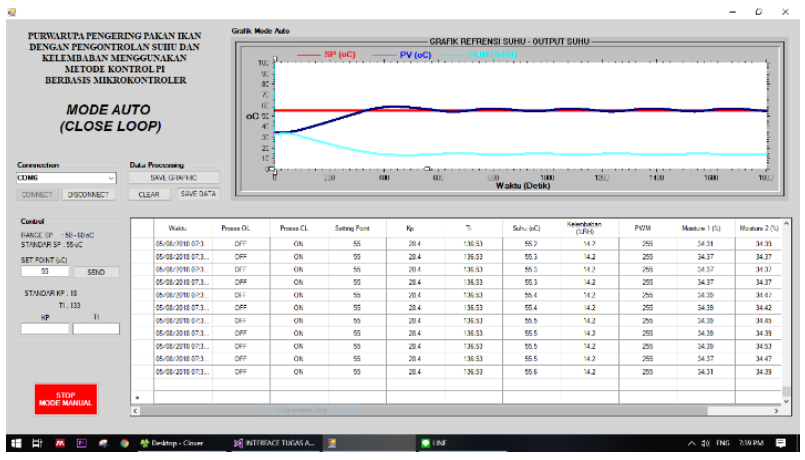

Gambar 11. Hasil pengujian pemberian nilai setpoint

Pada Gambar 11 diatas dapat dilihat bahwa sistem sudah berjalan dan pada grafik dan tabel sudah menunjukkan bahwa setpoint sudah sesuai dengan yang diberikan. Pengujian selanjutnya ialah pemberian nilai $\mathrm{Kp}$ dan $\mathrm{Ti}$. Pada pengujian ini, nilai $\mathrm{Kp}$ dan Ti harus dimasukkan kedua-duanya, jika hanya salah satu yang dimasukkan nilai maka akan mengeluarkan peringatan. Gambar 12 menunjukkan hasil pengujian pemberian nilai Kp dan Ti.

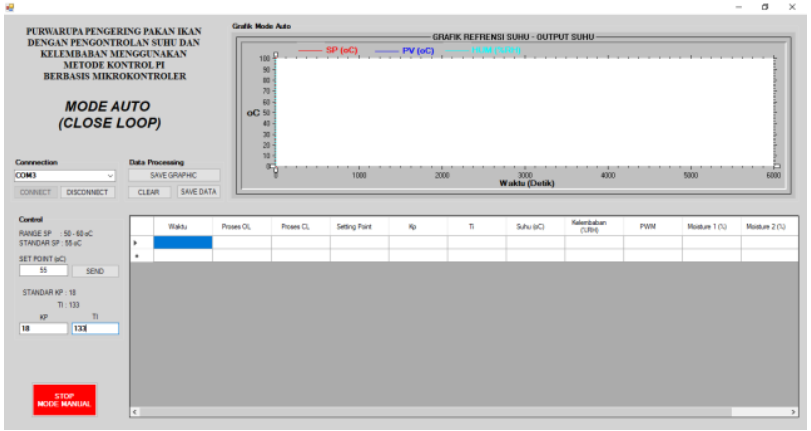

(a) Pemberian kedua parameter Kp dan Ti.

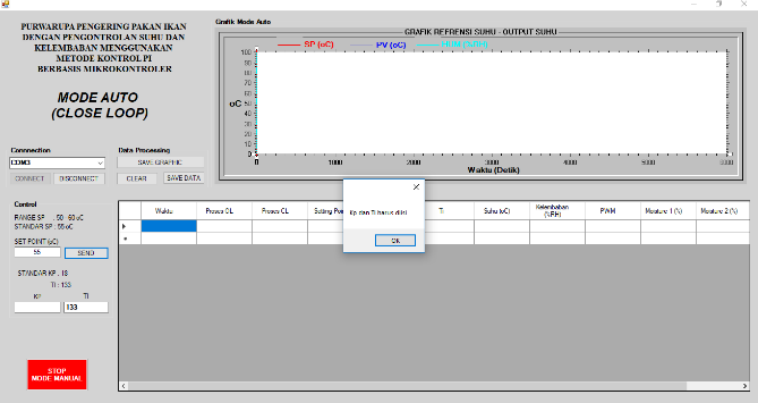

(b) Pemberian salah satu paramater (hanya Kp)

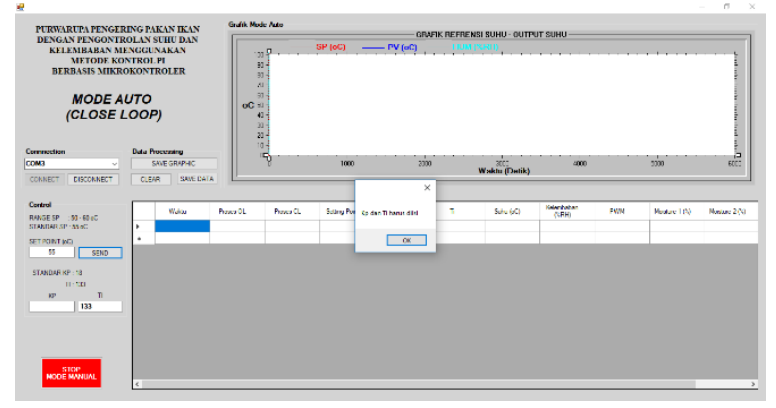

(c) Pemberian salah satu paramater (hanya Ti)

Gambar 12. Hasil pengujian pemberian nilai Kp dan Ti

Pengujian selanjutnya ialah penyimpanan data berupa grafik dan tabel. Gambar 13 menunjukkan hasil penyimpanan data grafik dan tabel.

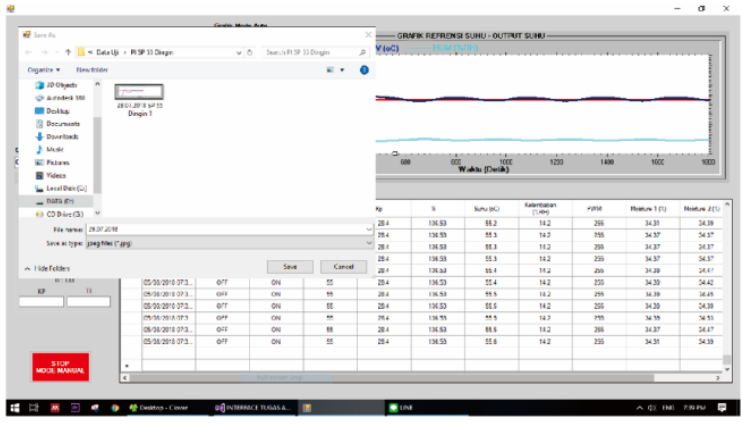

(a) Data grafik

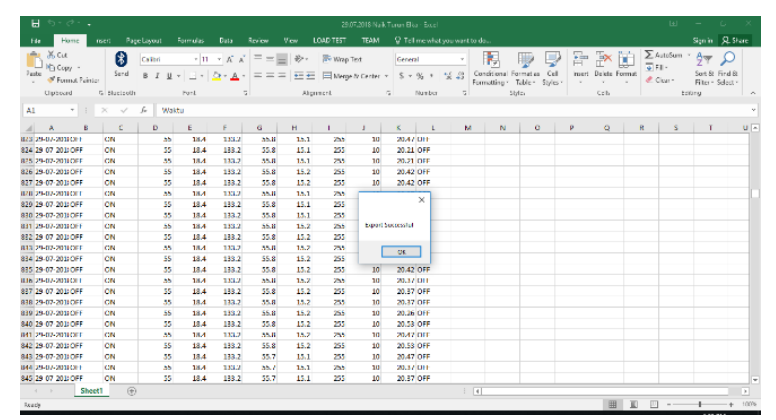

(b) Data tabel

\section{Gambar 13. Hasil pengujian penyimpanan data}

\subsubsection{Pengujian form mode Manual}

Pada pengujian form mode Manual dilakukan pengujian pemberian sinyal kontrol (u). Gambar 14 menunjukkan hasil pengujian pemberian sinyal kontrol $(\mathrm{u})$. 


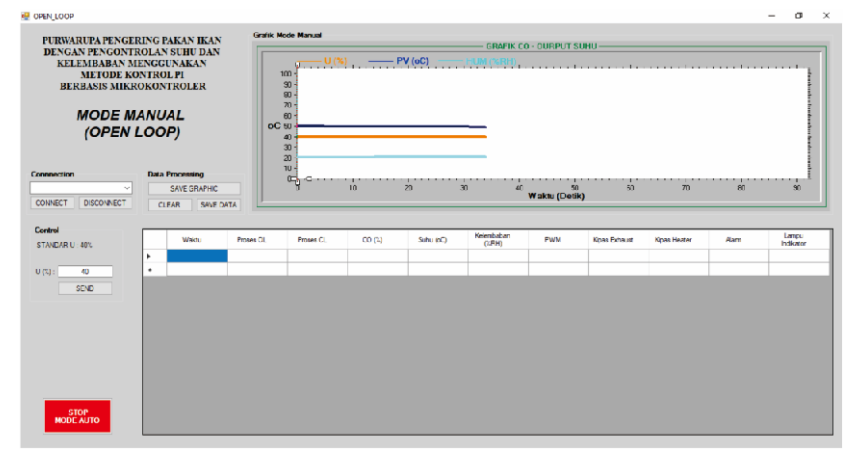

Gambar 14. Hasil pengujian pemberian sinyal kontrol (u).

Pada Gambar 14 diatas dapat dilihat bahwa sistem sudah berjalan dan pada grafik dan tabel sudah menunjukkan bahwa sinyal kontrol sudah sesuai dengan yang diberikan.

Pada mode Manual ataupun mode Auto terdapat jeda waktu ketika mengirimkan perintah "Send" ke alat pengering pakan ikan, pada percobaan yang dilakukan, alat akan mulai beroperasi rata-rata sebesar 0,58 detik setelah tombol "Send" ditekan. Sedangkan jeda waktu antara data yang terbaca di LCD dan di Visual Studio rata-rata sebesar 0.98 detik. Tabel 1 menunjukkan waktu tunda pengiriman perintah melalui Visual Studio. Tabel 2 menunjukan waktu tunda pembacaan data dari mikrokontroler.

Tabel 1. Waktu tunda pengiriman perintah dari Visual Studio

\begin{tabular}{|c|c|c|}
\hline Pengujian ke- & Status & $\begin{array}{c}\text { Waktu Tunda } \\
\text { (detik) }\end{array}$ \\
\hline 1 & Pengiriman setpoint & 0.6 \\
\hline 2 & Pengiriman setpoint & 0.5 \\
\hline 3 & Pengiriman setpoint & 0.6 \\
\hline 4 & Pengiriman setpoint & 0.7 \\
\hline 5 & Pengiriman setpoint & 0.5 \\
\hline \multicolumn{2}{|c|}{ Rata-rata waktu tunda } & 0.58 \\
\hline
\end{tabular}

Tabel 2. Waktu tunda pembacaan data dari mikrokontroler

\begin{tabular}{ccc}
\hline Pengujian ke- & Status & $\begin{array}{c}\text { Waktu Tunda } \\
\text { (detik) }\end{array}$ \\
\hline 1 & Pembacaan data & 1 \\
2 & Pembacaan data & 1.1 \\
3 & Pembacaan data & 0,9 \\
4 & Pembacaan data & 1 \\
5 & Pembacaan data & 0.9 \\
& Rata-rata waktu tunda & 0.98 \\
\hline
\end{tabular}

\subsubsection{Pengujian Alarm}

Pada Penelitian pengering pakan ikan ini terdapat 3 macam alarm. Diantaranya ialah alarm pakan siap, alarm overheat, alarm below setpoint. Alarm pakan siap aktif ketika kelembaban mencapai $10 \%$ RH dan kadar air telah mencapai $10 \%$. Gambar 15. Menunjukkan alarm pakan siap telah aktif. Alarm overheat akan aktif ketika suhu lebih $5^{\circ} \mathrm{C}$ selama 10 detik dan akan menampilkan tampilan seperti pada Gambar 16. Alarm below setpoint akan aktif ketika suhu tidak mencapai setpoint selama 30 detik dan akan menampilkan tampilan seperti pada Gambar 17.
Namun dengan catatan bahwa sebelumnya suhu pernah mencapai setpoint.

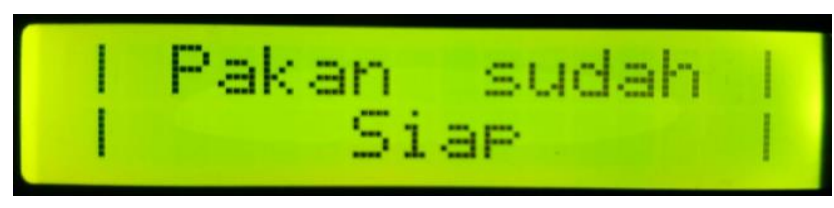

Gambar 15. Hasil pengujian alarm pakan siap.

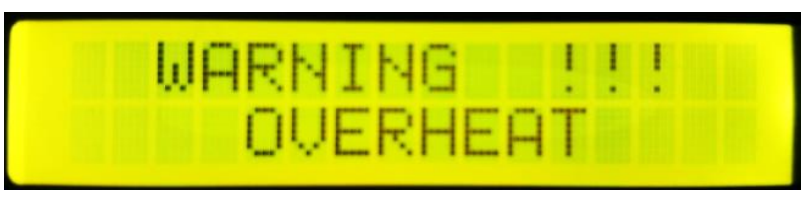

Gambar 16. Hasil pengujian alarm overheat.

$$
\begin{aligned}
& \text { Tid } \\
& \text { EEt.Firt. }
\end{aligned}
$$

Gambar 17. Hasil pengujian alarm below setpoint

\section{Kesimpulan}

Berdasarkan pengujian dan analisis yang dilakukan pada monitoring pada purwarupa pakan ikan melalui LCD dan Visual Studio telah berhasil dirancang. Pada pengujian form Login, form Menu Utama, form Auto,dan form Manual telah berhasil dilakukan. Pengujian Pengiriman setpoint dan sinyal kontrol berhasil dilakukan dengan baik. Pada pengiriman setpoint berhasil dilakukan dengan jeda waktu rata-rata sebesar 0,58 detik, dan jeda waktu pembacaan data rata-rata sebesar 0.98 detik. Pengujian alarm pakan siap, alarm overheat, dan alarm below setpoint juga telah berhasil sesuai dengan program yang telah dibuat.

\section{Referensi}

[1] Y. G. Mustikoaji, "Perancangan sistem monitoring dan kendali suhu pada oven kayu menggunakan minikomputer Raspberry Pi 3 dan Modul GSM," 2006.

[2] H. A. Yohannes, "Perancangan sistem akuisi data alat ukur arus, tegangan, hambatan dan suhu digital menggunakan koneksi Bluetooth pada ponsel cerdas Android," 2016

[3] H. A. Sandi, "Perancangan sistem akuisisi data multisensor melalui website berbasis android," 2017

[4] B. A. Luhung, "PERANCANGAN SISTEM ANTARMUKA BERBASIS HMI PADA PERANGKAT KERAS PENGEMASAN AIR MINUM.” 2015 
[5] E. ADRIONO, "PERANCANGAN SISTEM ANTARMUKA BERBASIS HMI (HUMAN MACHINE INTERFACE) PADA MESIN AUTO BALLPRESS PLANT DI PT.APAC INTI CORPORA"

[6] Gemamex, "HMI Manual"

[7] A. Kurniawan, "Pengenalan Bahasa C\#," 2004

[8] A. V. R. Microcontroller, "ATmega328P," pp. 1294.

[9] Bejo, Agus, C\&VAVR Rahasia Kemudahan Bahasa C dalam Mikrokontroller ATMega8535, Graha Ilmu,Yogyakarta, 2008. 